Pregledni članak UDK 111.84:32(045)

doi: $10.21464 /$ fi 40204

Primljeno 18. 3. 2019.

Michal Sládeček

Univerzitet u Beogradu, Institut za filozofiju i društvenu teoriju, Kraljice Natalije 45, RS-11000 Beograd sladecek7@gmail.com

\title{
Sveobuhvatnost i razložnost koncepcija dobra u raspravi političkog liberalizma i perfekcionizma
}

\begin{abstract}
Sažetak
U članku se tvrdi da John Rawls u svojoj kritici perfekcionizma sa stajališta liberalističke neutralnosti razmatra koncepcije dobra bez demarkacije između njih, odnosno bez njihova razlikovanja. Naime, Rawls ne razrješava pitanje o tome je li tu riječ o sveobuhvatnoj religijskoj odnosno filozofsko-etičkoj koncepciji ili je riječ o parcijalnom poimanju lokalnih vrijednosti, dobara i ciljeva. Bez obzira na spornu upotrebu pojma sveobuhvatnosti, neophodno je zadržati koncept razložnosti jer poimanja dobra, da bi bila relevantna u političkoj raspravi, trebaju biti relativno dobro zasnovana, konzistentna i koherentna. Kada se pođe od danih razlikovanja, može se tvrditi da u pojedinim slučajevima uvođenje razmatranja određenih dobara u rasprave o osnovnim principima političkog ustrojstva može biti dobro potkrepljeno $i$, sa stajališta razložnog pluralizma, moralno opravdano. Ipak, umjereni liberalistički perfekcionizam treba precizirati odnose li se političke odluke na stvaranje opcija, na promociju vrijednih ili na odvraćanje od bezvrijednih dobara i u skladu s tim treba odrediti doseg perfekcionističkih mjera.
\end{abstract}

Ključne riječi

neutralnost, liberalizam, perfekcionizam, razložne koncepcije dobra, doktrine, John Rawls

Budući da je u ovom znanstvenom radu riječ o debati između neutralnog političkog liberalizma i perfekcionizma, u uvodnom će se dijelu članka u kratkim crtama prikazati osnovna polazišta ove rasprave, prije svega, u svjetlu Rawlsove kritike perfekcionizma. U nastavku rada ispitivat ću osnovna teorijska određenja ideje o pojmu dobra, ujedno ukazujući na višeznačnosti i probleme na koje se nailazi kod tih određenja, a koje Rawls nije u dovoljnoj mjeri ispitao, imajući u vidu da je koncepcije dobra prvenstveno razumijevao kao sveobuhvatne. Također, pokušat ću ukazati na slabe strane pozicije koju brane Japa Pallikkathayil i Martha Nussbaum, po kojoj teorija pravde političkog liberalizma u nepotrebno velikoj mjeri inzistira na razložnosti koncepcija dobra u preklapajućem konsenzusu oko principa pravde. U završnom poglavlju analizirat ću načine na koje umjereni liberalistički perfekcionizam može odgovoriti na primjedbe neutralnog liberalizma, prije svega, na primjedbe Jonathana Quonga da perfekcionistička pozicija ne može objasniti kako je moguće razložno slaganje oko temeljnih principa pravde u uvjetima etičkog pluralizma.

Razlikovanje dva liberalizma možda je najradikalnija novost koja se pojavila u liberalističkoj teoriji u novije vrijeme. Prvi je liberalizam specifična ideologija, filozofija i teorija dobra sa svojim normama, idealima i vrijednosnim sistemom, dok se drugi ograničava na formuliranje skupa fer i nepristranih 
osnovnih principa političkog ustrojstva koje ne bi odbacila nijedna razložna osoba. Riječ je o poznatoj razlici sveobuhvatnog odnosno perfekcionističkog i političkog odnosno neutralnog liberalizma, a koja potiče od Rawlsa i njegova pokušaja koncipiranja liberalizma kao neovisne političke koncepcije. Politički liberalizam nastoji odgovoriti na pitanje: kakva trebaju biti načela i institucije političkog poretka koje bi bile pravedne i koje bi ujedno održavale društvo stabilnim u uvjetima razložnog pluralizma? Ta načela i institucije ne mogu se osnivati na općim ili sveobuhvatnim etičkim idejama i vizijama dobra. Naime, čak i u najpovoljnijim uvjetima pripadnici jednog društva neće postići slaganje oko kriterija izvrsnosti, odnosno oko etičkih ciljeva u čijem bi se pravcu institucije trebale usmjeravati. Ukoliko bi se u institucionalno uređenje ugradili ti ne-neutralni ciljevi, utoliko bi osobe ili grupe s drukčijim poimanjem izvrsnosti i poželjnih društvenih dobara bile potisnute i lišene mogućnosti za njihovo slijeđenje. S obzirom da je riječ o svrhama i vrijednosnim opredjeljenjima za koje pojedinci ili grupe smatraju da su od ključnog značaja po njih same ili po samo društvo i da potiskivanje tih vrijednosti predstavlja nepoštovanje tih pojedinaca i njihovih razboritih moći, oni će nastojati promijeniti zacrtane principe pravde. Usvajanjem principa koji bi bili ne-neutralni ili perfekcionistički u političke bi se osnove instaliralo permanentno stanje dubokih sukoba koji bi paralizirali institucionalnu funkcionalnost demokratskog sistema.

Politički liberalizam pretpostavlja da osnovni politički principi trebaju osobama garantirati pravo i slobodu da slijede vlastite životne ciljeve, no perfekcionizam postavlja i dodatne svrhe političkim aktivnostima. Po perfekcionizmu, odlučivanje o konstitutivnim političkim principima, kao i konkretno političko djelovanje, moraju uzimati u obzir širi skup dobara, individualnih i kolektivnih ciljeva, kao i omogućiti kreiranje i održavanje takvih uvjeta u kojima pojedinci mogu biti autonomni. Da bi ostvarile svoje ideje o dobrom životu osobe moraju djelovati u uvjetima u kojima mogu razvijati kapacitete za formiranje vlastitih ciljeva, kao i imati na raspolaganju određen broj opcija u kojima njihov samoizbor ima smisla. Društveni uvjeti koji su pod utjecajem politike trebaju omogućiti pojedincima da slijede vrijedne ciljeve, da streme k valjanim dobrima, pridržavaju se ispravnih koncepcija dobra, kao što, s druge strane, političko ustrojstvo i politička aktivnost trebaju odvraćati osobe od slijeđenja onih ciljeva, koncepcija i dobara koji su loši i štetni (usp. Raz 1988: 133; Wall 1998: 8).

Liberalistički perfekcionizam jest stajalište o političkom moralitetu koje podrazumijeva da je »osobna autonomija središnja komponenta ljudske dobrobiti i razvitka [human flourishing] « (Wall 1998: 2). Legitimno je da osnovni politički principi budu konstituirani na idejama koje mogu biti osporavane na razložan način, pod uvjetom da su omeđeni osnovnim ljudskim pravima i slobodama. Poboljšanje naših sposobnosti, razvoj potencijala, povećanje kapaciteta za formiranje i realiziranje koncepcije dobra, kao i proširivanje broja opcija legitimni su politički ciljevi kada ne ugrožavaju ničija prava, ne ograničavaju slobode drugih i ne uskraćuju autonomni izbor ciljeva, čak i ako ih većina smatra bezvrijednima.

Rawlsov politički liberalizam razvio se u opreci prema svakom pa i liberalističkom perfekcionizmu. Načela političkog poretka koja bi forsirala ideale ljudske usavršivosti, promovirala poboljšanje po liberalističkim mjerilima i zastupala individualističke vrijednosti bila bi kontroverzna i ne bi imala potporu osoba ili grupa s različitim poimanjima društvenih dobara i ciljeva: u idealnoj perfekcionističkoj državi oni koji su tradicionalistički orijentirani - ne brane individualizam i ne pridaju značaj preispitivanju svojih izbora - mogli 
bi se osjećati zapostavljenima i isključenima. Stoga je, s antiperfekcionističkog stajališta, neovisnost o svakoj koncepciji dobra, uključujući i liberalističke ideale samoodređenja i individualizma, bitna za liberalizam kao političku doktrinu. Ako liberalizam ovisi o posvećenosti sveobuhvatnim moralnim idejama, on je tek »još jedna sektaška doktrina« (Rawls 1985: 245-246).

\section{Rawlsova kritika perfekcionizma}

Rawls perfekcionizam određuje kao koncepciju po kojoj sveobuhvatna i objektivna teorija ili sistem vrijednosti treba odlučivati i o teoriji pravde, pri čemu se mogu razlikovati dvije varijante. Prva je varijanta nietzscheovska: perfekcionizam predstavlja teleološki princip po kojem su institucije, kao i dužnosti građana, konstruirane na taj način da maksimiziraju postignuća u vrijednim sferama poput umjetnosti, znanosti i kulture. Budući da su nositelji izvrsnosti izuzetni pojedinci, društveno uređenje i njegova načela vrednuju se u skladu s tim omogućuju li razvitak tih produktivnih karaktera (usp. Rawls 1999: 285-286). Druga je varijanta aristotelovska, pri čemu Rawls razlikuje striktni i ne-striktni perfekcionizam. Prvi je sa sadašnjeg stajališta očigledno neprihvatljiv jer po njemu vrijednosti postignuća imaju prioritet u odnosu na slobodu, tako da postignuća u antičkoj grčkoj znanosti, umjetnosti ili filozofiji opravdavaju ropstvo (usp. Rawls 1999: 286). Ne-striktni perfekcionizam ne pretpostavlja da izvrsnost može nadvladati osnovne slobode. Premda tvrdi da određeni državni resursi nužno trebaju biti izdvojeni za perfekcionističke svrhe, u slučaju kada se ti zahtjevi sukobljavaju sa zahtjevima za primarnim dobrima, prvenstvo daje vrijednostima kao što su: osnovna prava i slobode, poštovanje, dobrobit, sloboda biranja profesije i sl. Iako intuitivno prihvatljiv i prihvaćen od brojnih teoretičara, perfekcionizam sa svim svojim varijantama, uključujući i umjereni, po Rawlsu, nailazi na teškoće, s obzirom na to da su njegova načela u koliziji s principom jednake slobode.

Perfekcionizam nailazi također i na problem neophodnosti da se bitno različita postignuća rangiraju po određenim vrijednosnim kriterijima, a po kojima se dalje određuju smjernice za osnovnu strukturu društva. S obzirom na to da ne postoje takvi objektivni kriteriji koji bi rangirali vrijednosti i dobra međusobno različita po vrsti, ni osobe neće postići suglasnost oko kriterija izvrsnosti, odnosno prioriteta koje treba dati određenim dobrima i aktivnostima. Uspostavljeni prioritet, formuliran kao politički zahtjev, podrazumijevao bi ujedno državnu prisilu u raspoređivanju resursa i prednosti u jednom pravcu i tako doveo u neravnopravni položaj one osobe koje imaju različite prioritete. ${ }^{1}$

Ipak, ključni argument protiv perfekcionizma nije neodređenost ili nedostatak standarda procjene izvrsnosti pojedinih dobara ili aktivnosti, već je najbitnija napomena da u prvobitnom položaju strane koje konstituiraju principe pravde, s obzirom na to da nemaju zajedničke ciljeve, nemaju razlog primijeniti perfekcionističke principe kao osnovne (usp. Rawls 1999: 288). Argument ne poriče da se unutar partikularnih oblasti i tradicija mogu uspostaviti pouzdani vrijednosni sistemi po kojima bi se procjenjivala valjanost znanstvenih

To se, po Rawlsovu mišljenju, razlikuje od indeksa primarnih dobara. Formuliranje i prihvaćanje tog indeksa neophodno je razlučiti od formuliranja i prihvaćanja standarda izvrsnosti. Standardi izvrsnosti podrazumijevaju unaprijed utvrđene svrhe, neovisne o proceduri na osnovi kojih su oni utvrđeni, pa i neovisne o izboru koji zastupaju strane u društvenom ugovoru. Primarna dobra (sloboda, prava, zdravlje, materijalna dobra itd.), s druge strane, nisu svrhe za sebe, već čine neophodne uvjete da bi osobe mogle odrediti vlastite ciljeve i vrijednosne prioritete (usp. Rawls 1999: 288). 
ili umjetničkih dostignuća. Moguće je uspoređivati ta postignuća. Premda standardi njihove procjene ne mogu služiti za utemeljenje osnovnih principa pravde, oni imaju važnu ulogu u ljudskom životu. Standardi izvrsnosti mogu biti dovoljno jasno definirani, tako da sama mogućnost neodređenosti nije razlog za njihovu neprimjerenost da funkcioniraju kao principi distribucije prava i dobara. ${ }^{2}$ Ipak, bez obzira na to što su ti ideali priznati kao vrijedni, oni trebaju biti realizirani unutar granica slobode udruživanja: osobe se udružuju da bi promovirale svoje kulturne i umjetničke interese na isti način na koji se udružuju u religijske zajednice (usp. Rawls 1999: 289). Budući da osobe nemaju istovjetne interese i ciljeve udruživanja, ne bi bilo pravedno da jedna grupa zastupnika interesa ili ciljeva traži za sebe veća prava i resurse zato što promovira intrinzične vrijednosti.

U knjizi Politički liberalizam, Rawls ne revidira bitno svoju kritiku. Rasuđivanja o dobru dio su pozadinskih uvjeta pravednosti, ali ne i javnog uma u kojem se odlučuje o supstantivnim principima pravde osnovne strukture i koji isključuje one koncepcije koje su sporne - one oko kojih se ne može postići razložna suglasnost građana. Takve su kontroverzne koncepcije religijske, filozofske i etičke doktrine o krajnjim svrhama, životnim ciljevima, vrijednostima i dobrima. Konsekventno tomu, ni liberalizam sa svojim vrijednostima, kada se predstavi kao sveobuhvatna perfekcionistička teorija, ne može imati pretenzije da njegovi principi budu prihvaćeni kao načela političke pravde.

\section{Sveobuhvatne koncepcije}

Pojedini su autori već primijetili da kritika perfekcionizma od strane neutralnog liberalizma počiva na nedovoljno određenom smislu i nedovoljno konzistentnoj upotrebi pojmova. Riječ je o pojmovima koji označavaju vrijednosti, takve koje bi perfekcionistička politika trebala čuvati, protežirati ili unaprjeđivati (usp. Chan 2000: 8). ${ }^{3}$ Neutralni liberalizam pretpostavlja da perfekcionizam legitimira državnu akciju koja bi bila zasnovana doktrinarno, odnosno na koncepciji dobra ili sveobuhvatnom etičkom ili religijskom sistemu, ali također, i na manje supstancijalnim osnovama, kakva je ideja o ljudskom razvoju, tj. napredovanju, afirmaciji individualiteta, autonomiji, ljudskoj prirodi ili kapacitetima. Ipak, to nisu samoočigledne ideje: samorazvoj, autonomija, individualitet itd. mogu se očitovati u brojnim varijantama i mogu zahvaćati širok dijapazon interpretacija vrijednosti. Konačno, u pojedinim slučajevima se kao jedna od pretpostavljenih ne-neutralnih svrha političke akcije označavalo i omogućavanje ostvarenja subjektivno shvaćenog »smisla života«, kao i idiosinkratičnih »načina« ili »stilova« života, pojedinca ili kolektiviteta. Budući da se ti posljednji slučajevi poklapaju s obranom neutralne države, ${ }^{4}$ odredba perfekcionizma može se primijeniti u prva dva smisla, odnosno na politike koje su u skladu s nekom općom koncepcijom - metafizičkom, religijskom ili etičkom - o svijetu, istini i vrijednostima, kao i one politike koje bi stvorile, održavale i omogućavale realiziranje određenih opcija koje se smatraju vrijednima. Ta se dva smisla perfekcionizma, međutim, bitno razlikuju. Kada su dio religijske doktrine, koncepcije dobra su sveobuhvatne, s obzirom na to da najčešće na cjelovit način sadržavaju kozmologiju, metafiziku i etiku koja normira najrazličitije aspekte individualnog djelovanja, shvaćanje dobrog života, kao i međusobne odnose pojedinaca. U brojnim slučajevima religijski zasnovane koncepcije dobra također su i ekskluzivističke, odnosno teže isključivanju ili osudi onih koji ne podržavaju dane teološke postavke i imaju različita etička uvjerenja. Očigledno, politički poredak koji bi bio za- 
snovan na takvim koncepcijama bio bi represivan i diskriminatoran pa kao takav neprihvatljiv sa stajališta liberalističke ideje pravde.

No religijske se doktrine u kritici navode kao paradigmatični primjeri sveobuhvatnih doktrina ne samo zato što je njihova primjena normativno neprihvatljiva kada nastoji regulirati političku, socijalnu i privatnu sferu prema jedinstvenim vrijednostima obaveznim za sve građane nego i zbog širih društvenih destabilizirajućih posljedica. Rawls govori da je poredak u kojem je postojao pokušaj etabliranja jedne religijske koncepcije kao dominantne u konfesionalno mješovitom društvu doveo do pobune, nasilja i vjerskih ratova, zbog čega je moralo doći do uspostavljanja vjerske tolerancije i, posljedično tome, do davanja prednosti neutralnim političkim principima u odnosu na individualne i kolektivne vizije dobrog života. Teže je, ipak, pokazati to na slučaju filozofskog sistema čija su načela usvojena kao konstitutivna u političkoj sferi. Budući da su filozofske koncepcije kompleksni pojmovni i aksiološki sistemi, moguće je smisleno postaviti pitanje odgovaraju li određene politike općim, recimo liberalističkim, načelima, ali ne i pitanje odgovaraju li ili odudaraju legislativni i sudski principi od kantovske, millovske ili dworkinovske varijante liberalizma. ${ }^{5}$ Pojedini režimi bili su zasnovani na filozofskim, doduše izobličenim, rousseauovskim i marksističkim idejama, no jakobinski režim i realni socijalizam ipak nisu bila liberalno konstituirana uređenja, tako da se ti primjeri ne dotiču perfekcionističkog liberalizma kao poimanja vrijednosti na kojoj bi počivali konstitutivni elementi političke zajednice.

Premda ima empirijsku podlogu, može se ipak primijetiti da ta primjedba ne pogađa sasvim srž argumenta Rawlsova političkog liberalizma. Budući da je u njemu riječ o shemi, odnosno o postuliranju principa pravde koje bi

Za kritiku Rawlsova odbacivanja umjerenog perfekcionizma sa stajališta neodređenosti vidi više u: McCabe 2000: 315.

3

Joseph Chan navodi fraze koje zastupnici neutralnosti koriste da bi označili nepolitičke vrijednosti. Upravo njih perfekcionističke političke koncepcije nastoje uvesti u legitimnu sferu politike, pri čemu ti zastupnici ne uvažavaju razlike u značenjima sa svojim suptilnostima i nijansama. Povodom kritike perfekcionizma Thomasa Nagela u knjizi Equality and Partiality, Chan skreće pozornost na Nagelovu neujednačenu upotrebu pojmova, tako da ne-neutralna teorija u političke principe uključuje »vrijednosti«, »dobro za ljudska bića«, »moralne ili religijske koncepcije«, »smisao života« itd. (usp. Chan 2000: 10-11). U daljnjem tekstu nastojat ću pobliže odrediti te kategorijalne distinkcije koje ponekad ostaju van vidokruga u polemici antiperfekcionizma i perfekcionizma.

Robert Nozick, kao zastupnik neutralne države, složio bi se vjerojatno s tvrdnjom da država treba otvoriti vrata svim načinima života koji ne ugrožavaju slobodu drugih. Za tu priliku, pojam načina života upotrijebljen je u smislu u kojem je njihova vrijednosna komparacija bespredmetna. Načini života mogu, međutim, imati etičke konotacije kada se pod njima podrazumijeva nemarno i povređujuće ponašanje, samoživost i neodgovornost prema članovima obitelji ovisnima o danoj osobi i sl. Ne bi bilo opravdano ako bi se takvo ponašanje smatralo neotuđivim dijelom autonomije koje ni pod kojim uvjetima nije podložno sankcijama države. S druge strane, poligamija, ravnodušnost prema umjetnosti i život ispunjen vulgarnim zadovoljstvima aktivnosti su koje država nema pravo zabranjivati pa ni, makar sa stajališta neutralnog liberalizma, odvraćati osobe od njih (usp. Schefczyk 2012: 545; Waldron 1989: 1133). Jeremy Waldron smatra da Razovo, kao i svako drugo perfekcionističko poimanje moralnosti, pretpostavlja da država ima opravdanje intervenirati i u onim sferama autonomnog ponašanja koje se ne tiču interesa drugih osoba.

5

Sam Rawls filozofske teorije Immanuela Kanta, Johna Stuarta Milla i Ronalda Dworkina analizira kao primjere sveobuhvatnog liberalizma koje, doduše, imaju svoju vrijednost kao dio »kulture u pozadini« i mogu imati određenu ulogu kao podrška političkom liberalizmu, ali ne bi se moglo očekivati njihovo prihvaćanje kao principa društvene suradnje od strane svih građana (usp. Rawls 1998: 251). 
racionalne osobe izabrale u prvobitnom stanju, nije riječ o tome jesu li realni pojedinci u danim okolnostima izabrali kao osnovu pravde načela filozofske doktrine, odnosno perfekcionističkog liberalizma. Politički liberalizam govori o principima društvene suradnje koje bi svi slobodni i jednaki pojedinci prihvatili kao nepristrane i pravedne u situaciji u kojoj im nisu poznati status, obrazovanje, interesi, kao ni njihovi životni planovi i koncepcije dobra. Kritika Rawlsove ideje sveobuhvatnosti pokazuje da religijske doktrine i liberalističke filozofsko-etičke teorije, kada se predstave u svojim perfekcionističkim vidovima (tj. kao političko poticanje određenih vrijednosti), na različit način određuju društvenu kooperaciju i utječu na političku sferu, slobode i prava, pa na različit način bivaju legitimne ili nelegitimne. Rawls tvrdi da se

»... neka koncepcija dobra obično sastoji od više ili manje određene sheme krajnjih svrha, odnosno svrha koje želimo ostvariti radi njih samih, kao i od povezanosti s drugim osobama i lojalnosti prema raznim grupama i udruženjima.« (Rawls 1985: 233)

Religijske su »sheme krajnjih svrha« bitno različite od filozofsko-etičkih. Također, Rawls ovdje pridodaje i pretpostavku da te koncepcije imaju i socijalne forme, odnosno da konstituiraju veze među njihovim zagovornicima. Za razliku od konfesija i ideologija, filozofske teorije nemaju takav skup lojalnih privrženika koje bi povezivala shema obveza, tako da je teško zamisliti društvo u kojemu su sve osobe kantovci, millovci i dworkinovci. Liberalističke filozofske pozicije oslanjaju se na skup uvjerenja i intuicija koje postoje u jednom liberalnom, demokratskom i prosvijećenom društvu. Nastoje ih obrazložiti i organizirati u određenu koherentnu, ali ne nužno i sveobuhvatnu formu. ${ }^{6}$ Potičući autonomiju i jednaku distribuciju resursa, kapaciteta, životnih šansi i drugih primarnih dobara, one ne moraju dovesti u neravnopravan položaj takve osobe koje više vrjednuju kolektivni način života, vezanost uz dogme ili odricanje od materijalnih dobara. Naprotiv, mogu smatrati da individualistički i kolektivistički, hedonistički i isposnički, bogat društveni i samotnjački život mogu napredovati jedan pored drugog samo uz mogućnost autonomnog izbora, optimizacije vlastitih preferencija i jednakih uvjeta za sve.

Konačno, filozofskim sistemima inherentni su argumentativni pristup, obrazlaganje vlastitih pretpostavki, pokušaji njihovog koherentnog formuliranja, kao i refleksija o posljedicama i prihvatljivosti koje ta načela imaju u primjeni. Sve to čini filozofske koncepcije otvorenijim i manje rigidnim u odnosu na sveobuhvatnost religijskih doktrina, što čini diskutabilnim svrstavanje i jednih i drugih, bez jasnog distingviranja, u jedinstvenu klasu koncepcija dobra.

\section{Razložne koncepcije}

Kao što je poznato, Rawls kao neophodna svojstva koje građanin treba imati navodi dvije moralne moći: sposobnost za osjećanje pravde i sposobnost za koncepciju dobra (usp. Rawls 1998: 116). Bez obzira na to što ta druga sposobnost podrazumijeva, osim moći formiranja koncepcije dobra, također i moć racionalnog slijeđenja i revizije dane koncepcije (usp. Rawls 1998: 63, 349, 352), pojedini kritičari smatraju da Rawlsov politički liberalizam polazi od jake pretpostavke identifikacije građana sa svojom doktrinom odnosno poimanjem dobra. Smatraju da je politički liberalizam uvođenjem sposobnosti za formiranje razložne koncepcije kao jednog od uvjeta da pojedinac bude priznat kao građanin, $\mathrm{tj}$. sudionik u društvenoj kooperaciji, postao preuzak i prerestriktivan.

Pallikkathayil i Nussbaum predlažu liberalističku koncepciju pravde koja ne bi bila zasnovana na razlikovanju razložnih i nerazložnih doktrina (usp. Pallik- 
kathayil 2016: 186-187), odnosno koja bi razložnost doktrina definirala u skladu s time podržavaju li je razložni građani (usp. Nussbaum 2011: 26). Opravdanje principa pravde, koje liberalizam razvija i na osnovi kojih bi se mogla pravdati državna prisila, trebalo bi biti prihvatljivo svim razložnim građanima. Specifičnost rawlsovskog političkog liberalizma jest tvrdnja da će građani principe pravde opravdavati kao zastupnici razložnih koncepcija dobra na taj način što će utvrđivati odgovaraju li principi pravde tim koncepcijama. U skladu s tim, ta vrsta liberalizma kao posljedicu ima isključivanje iz odlučivanja o principima pravde, ali i šire, iz sudioništva u politici cijelih skupina osoba - onih koje brane nerazložne koncepcije dobra. Inkluzivniji i manje restriktivan pristup omogućio bi da u politički diskurs budu uključene sve osobe koje uvažavaju druge kao ravnopravne i neovisne subjekte političkog odlučivanja. Koncepcija koja bi bila alternativna političkom liberalizmu tretirala bi načela političke kooperacije kao neovisna o doktrinarnoj perspektivi sudionika u političkim procesima. Ona bi podrazumijevala da su uvjeti društvene kooperacije pravedni ako na primjeren način usklade zahtjeve građana i grupa, bez obzira na uvjerenja koje građani i grupe imaju kada iznose te zahtjeve (usp. Pallikkathayil 2016: 185).

Ipak, pitanje je može li politička koncepcija koja zaobilazi vrijednosna uvjerenja osoba pledirati da bude moralno zasnovana, odnosno da bude konstituirana na uvažavanju integriteta, poštovanju osobnosti i autonomiji pojedinca. Početna pretpostavka političke koncepcije kao moralne jest da građani afirmiraju određene vrijednosti, da su one organizirane u više ili manje koherentnu cjelinu, da građani pridaju značaj tim vrijednostima (odnosno shvaćaju ih kao konstitutivne po njihovo sebstvo) i da njihovo neuvažavanje u javnom diskursu doživljavaju kao diskriminaciju vlastite osobnosti. Rawlsova pozicija ne mora voditi k zaključku da su osobe koje brane nerazložne doktrine i same nerazložne i da te osobe trebaju biti izolirane ili isključene iz političkih aktivnosti kao nekompetentne. Osobe, međutim, ne mogu bezuvjetno tražiti jednako uvažavanje za vlastite vrijednosne sisteme: kada angažiranjem u skladu sa svojim vrijednosnim uvjerenjima sebe postavljaju kao jedinog mjerodavnog arbitra u argumentacijskom polju javnog diskursa, kada svom viđenju dobra daju privilegiran položaj ili kada njihove doktrine zagovaraju diskriminaciju drugih i uskraćivanje osnovnih sloboda, tada postoji osnova da se takav angažman ne uzima u obzir u političkoj deliberaciji.

Bez obzira na to što su koncepcije dobra organizirane na relativno koherentan način, na osobama je da ih interpretiraju, javno opravdaju i usklađuju sa zahtjevima pravednosti u javnoj sferi. I kada je doktrina prošla test razložnosti, kada je u skladu s javnim umom, odnosno kada njene vrijednosti nisu u koliziji s osnovnim postavkama koje su prihvatili svi razboriti sudionici u političkoj deliberaciji, osobe ipak mogu koristiti doktrinu na nerazložan način, primjerice pridajući znatno veći značaj jednoj vrijednosti, zanemarujući pritom neke druge (usp. Weithman 2017: 405). Također, građani mogu priznati da je

Da obilježje »sveobuhvatni liberalizam« vodi u zabludu napominje i Gerald Gaus, imajući u vidu da ono »uključuje sve, od istinski sveobuhvatnih liberalizama kao sekularnih filozofija velikog raspona do kantovskih liberalnih teorija političke pravde koje su, kako se čini, spojive sa širokim krugom pojmova o vrijednosti, društvenoj spoznaji i sebstvu. (...) Millovski se liberalizam, kao teorija individualnog razvoja, kako izgleda, odnosi na bogatu teoriju dobrog života, dok se kao utilitaristička teorija odnosi na cjelokupnu teoriju o dobrom i pravednom. S druge strane, kada se razumije jednostavno kao shvaćanje liberalizma koje počiva na principu povrede (harm), millovski liberalizam neće biti obuhvatniji od kantovskoga liberalizma (...)« (Gaus 2004: 111-112). 
jedan dio njihove koncepcije nerazložan i da ga »stave u zagradu « kao neprikladan za obranu od strane javnog uma ili da pojedine dijelove interpretiraju kao irelevantne za političku raspravu. ${ }^{7}$ Druge značajne vrijednosti kojima oni streme i dalje mogu imati dovoljnu težinu da bi opravdavale i podupirale nepristrano zasnovan poredak.

Nussbaum svoju kritiku Rawlsova političkog liberalizma zasniva na kritici pojma razložnosti, odnosno stajališta da razložne osobe afirmiraju samo razložne sveobuhvatne doktrine. Jedna od karakteristika razložne doktrine jest da

»... predstavlja upotrebu teorijskog uma: ona obuhvaća najvažnije religijske, filozofske i moralne aspekte ljudskog života na manje ili više konzistentan i koherentan način. Ona organizira i karakterizira priznate vrijednosti tako da budu suglasne jedna drugoj i da izražavaju razumljiv pogled na svijet.« (Rawls 1998: 93)

Taj Rawlsov kriterij razložnosti, međutim, označuje brojne doktrine koje racionalne osobe zagovaraju kao nedosljedne, iracionalne i epistemološki neuvjerljive. S druge strane, Nussbaum svojim razlikovanjem teorijske i etičke razložnosti smatra da je državi dozvoljeno da, kada se razložnost upotrebljava u etičkom smislu, kritizira i odbaci doktrine koje se suprotstavljaju osnovnim pravima, primjerice takve koje zagovaraju ropstvo ili rodnu neravnopravnost (usp. Nussbaum 2011: 27). Ipak, ni država ni građani nemaju prava na to da jedni drugima »gledaju preko ramena « i provjeravaju brane li oni neko vjerovanje koje je iracionalno ili prihvaćaju bespogovorno podređivanje autoritetu. Ukoliko bi država i građani to činili, utoliko bi iskazali nepoštovanje prema osobama s iracionalnim i dogmatskim stavovima, odnosno prema njihovom kapacitetu za razložnošću.

Osobe koje zagovaraju astrologiju ili ispovijedaju neku od New Age religija trebaju se tretirati kao etički razložne ako priznaju sugrađane kao ravnopravne i vrijedne poštovanja, kao što se moraju respektirati njihove doktrine čak i ako ne ispunjavaju epistemološke kriterije, nisu koherentne, ne uvažavaju znanstvene dokaze i ne modificiraju se po evidenciji (usp. Nussbaum 2011: 26). Takve kriterije ne ispunjavaju ni brojne druge doktrine, kao što je kršćanstvo kada preuzima logički nekoherentan koncept Svetog Trojstva ili kada tvrdi da se božanska milost ne može racionalno opravdati. Umjesto da se kao uvjet razložnosti prizna jedino etička kompatibilnost doktrina s osnovnim principima pravde, Rawlsov politički liberalizam uvodi, po Nussbaum, suviše stroge epistemološke kriterije razložnosti kao uvjet prihvatljivosti doktrine u političkom diskursu.

Moglo bi se uputiti nekoliko primjedbi takvoj kritici koncepta razložnosti doktrina. Prvo, astrologija i New Age religije kao sveobuhvatne doktrine nemaju značajan etički sadržaj i zahtjev ih za razložnošću može naprosto ignorirati. Politički liberalizam uzima u obzir samo etički relevantne doktrine, što eliminira astrologiju i New Age religije kao značajne za razmatranje koje se odnosi na moralne osnove političkih principa. Naravno, osobe koje ih zastupaju brane i pojedina etička stajališta koja se trebaju uzimati u obzir, prihvaćaju ih ili odbacuju kao valjana i samo zbog toga što osobe zastupaju neosnovana shvaćanja njihovo bi ignoriranje predstavljalo povredu njihova ravnopravnog poštovanja kao osobnosti. Drugo, uvjet da osobe u javnoj sferi na razložan način brane, opravdavaju, modificiraju i revidiraju svoja kako doktrinarna tako i od doktrine odvojena pojedinačna stajališta i vrijednosti eliminira pojedine koncepcije kao neprihvatljive upravo zbog njihovog teorijskog sadržaja. Antivakcinalni pokret može se tumačiti kao obrana moralnog autonomnog izbora, pa ipak je to stajalište neprihvatljivo zbog toga što se 
ne može racionalno opravdati. Treće, doktrine mogu imati »internu racionalnost«, odnosno mogu se konsekventno i koherentno izvoditi zaključci iz tvrdnji koje se temelje na vjeri, a ne na evidenciji i dokazu. Sveto Trojstvo smislen je koncept onome koji prihvaća Nicejsko vjerovanje, odnosno kada se on uklapa u ostale elemente kršćanske doktrine. Sličan slučaj dosljednosti i koherencije može se naći i u raspravama o ideji predestinacije i božanske milosti, dok se uskrsnuće, bez obzira na natprirodno podrijetlo, u kršćanskoj doktrini uzima kao povijesna činjenica, a ne slijepi čin vjere. Bilo bi pretjerano reći, na način na koji to sugerira Nussbaum, da je kršćanstvo rawlsovski nerazložno jer je nekompatibilno s epistemičkim kriterijima. Četvrto, građani koji nisu u stanju da bar u osnovi opravdaju svoje stavove i da ih prikažu na smislen način neće biti u stanju ni da brane, pravdaju ili obrazlože principe pravde jedni drugima. Rawls to izražava stavom o komplementarnosti razložnog i racionalnog, odnosno nepristranosti suradnje i slijeđenja koncepcije dobra (usp. Rawls 1998: 86).

Kada drugi sudionici u političkom forumu za određenu doktrinu tvrde da nije dobro zasnovana da bi bila uzeta kao relevantna za odlučivanje, oni to čine na legitiman način ako ukažu da su njena stanovišta nepouzdana, nekoherentna i namjerno ideološki jednostrana, a ne samo etički nerazložna. Stajališta koja su nerazložna u tom punom smislu također mogu pledirati na stjecanje političke relevantnosti, kao u slučaju kada se obavezno cijepljenje postavi kao političko pitanje. Politički zahtjev formulira se kao sloboda osoba da ne budu cijepljene, odnosno pravo roditelja da ne cijepe vlastitu djecu. Znanstveni ili pseudoznanstveni antivakcinizam svoje tvrdnje želi potkrijepiti medicinski i može mu se prigovoriti namjerno ignoriranje onih epidemioloških, imunoloških, evolucijsko-bioloških i statističkih spoznaja koje mu ne idu u prilog. Religijski antivakcijski argument da je cijepljenje neprikladno zadiranje u Božje poslove miješa međusobno različite domene znanosti i religije. Zavjerenički antivakcinizam pretpostavlja da su farmaceuti i liječnici na svim razinama i u svim državama povezani u korupcijsku konspirativnu mrežu prikrivanja i zataškavanja, čime, suprotno zdravom razumu, tvrdi da se čitave strukovne grupe u gotovo stopostotnom razmjeru rukovode samo sebičnim, a ne i etičkim obzirima. No stajalište antivakcinizma nije etički nerazložno, bar u slučaju kada se formulira kroz neutralne razloge autonomije pojedinaca. ${ }^{8}$ Ta koncepcija nije diskriminatorska i nije usmjerena na ograničavanje prava drugih osoba ili skupina, na sužavanje osobnih i političkih sloboda, poricanje jednakosti i nepoštovanje drugoga zbog njegove vizije dobrog života. Teorijski razlozi, ipak, opravdavaju isključenje te koncepcije iz domene rasprave o konstitucionalnim osnovama, odnosno opravdavaju da se pristajanje ili nepristajanje na cijepljenje ne tretira kao pitanje temeljnih prava pojedinaca ili grupa. Pritom se i dalje ostavlja sloboda da se o razlozima protiv cijepljenja raspravlja unutar medicinske struke, religijske grupe ili bilo koje skupine zainteresiranih pojedinaca, kao što se mora dopustiti da se jednom dokaže da su cjepiva štetna, da oni koji ih primjenjuju idu u pakao i da zaista postoji opće rasprostranjena zavjera radi kontroliranja populacije ili širenja pojedinih bolesti.

To da doktrine trebaju biti razložne ne znači da su sve njihove postavke prihvatljive i relevantne po javni um, a još manje da one trebaju biti potvrđene kao istinite. O pojmovima razložnosti i istinitosti u okvirima Rawlsova političkog liberalizma vidi više u: Zelić, Baccarini 2011; Zelić 2015.
Za ovu priliku, negativne konzekvence te koncepcije mogu se ostaviti po strani jer se ovdje ispituje može li se ona legitimno uvesti u politički diskurs o konstitucionalnim osnovama, a ne rezultati koji će slijediti iz primjene politike koja uvažava to stajalište. 
Teme implicitne u ovom odjeljku predmet su neiscrpnih i iznijansiranih debata o političkom liberalizmu i traže daljnju razradu. Pojedini stavovi moje kritike mogu se, pretpostavljam, jasno razabrati. Da bi bili okarakterizirani kao razložni, neki od aspekata doktrine trebaju biti racionalni, dosljedno branjeni, tolerirati drugačija mišljenja i priznati osnovna prava i slobode, dok drugi mogu počivati na vjeri kao opreci razuma i ne odnositi se na socijalni, politički i moralni život. Ipak, to ne govori protiv teorijske razložnosti, već problematizira koncept sveobuhvatnosti kao potpuno zatvorene i sveprožimajuće cjeline. ${ }^{9}$ Također, od zastupnika koncepcije dobra očekuje se minimum koherencije kod njihova zastupanja i opravdavanja, kao što se na praktičnom planu od tih zastupnika očekuje uviđanje i prihvaćanje posljedica koje slijede iz njih.

\section{Umjereni perfekcionizam i primjedbe}

Umjereni liberalni perfekcionizam polazi od stanovišta da postoji dobro ili klasa dobara koje nijedan građanin neće imati razloga odbiti, $\mathrm{u}$ istom smislu u kojem razboriti građani ne osporavaju osnovne principe pravde, kao što su principi jednakosti i individualnih prava građana. Tako postoji suglasnost osoba oko toga da je ovisnost o teškim drogama nešto loše, a da su umjetnost, prijateljstvo i život u skladu sa samostalno izabranim vrijednostima nešto dobro, bez obzira na to što te osobe mogu zastupati ili zastupaju različite sveobuhvatne doktrine (usp. Mang 2013: 302-304; Chan 2000: 12; Arneson 2006: 215-216). ${ }^{10}$ Umjereni perfekcionizam ne povlači stav da je neophodno da se politika treba kreirati na perfekcionističkim načelima, odnosno da država mora štititi i promovirati objektivno vrijedna dobra bezuvjetno. Za razliku od neutralnosti, on podrazumijeva da je dozvoljeno i legitimno da određena politika štiti i promovira vrijedne opcije, ${ }^{11}$ pri čemu su one zasnovane na poimanju o objektivno vrijednim dobrima na ne-sektaški način. Politička intervencija može se pravdati kao ne-paternalistička ako podržava javna dobra koja bez takve intervencije neće biti dostupna najširem krugu osoba, bilo da politika ta dobra stvara, subvencionira ili promovira i tako potiče osobe da odaberu vrijedne opcije. Dok paternalizam podrazumijeva zabrane ili ograničenja onih aktivnosti koje su prihvaćene i odobrene od strane subjekta, mjere države, koje Raz i drugi perfekcionisti legitimiraju kao opravdane, trebaju stvoriti okruženje ili kontekst u kojem su osigurane brojne opcije u okviru kojih osoba ima mogućnost za izbor među njima i na taj način afirmirati vlastitu autonomiju (usp. Raz 1988: 417-418). Ipak, odluke o tome koje je opcije potrebno poticati vrijednosno su selektivne, no obveza je države stvoriti višestruke vrijedne opcije koje će osobe različito procjenjivati ili koristiti, ali neće imati razložnu primjedbu da su one štetne, bespotrebne ili diskriminirajuće.

Prema tome, osnovni principi pravde i odluke u vezi s njima, premda se ne trebaju zasnivati na sveobuhvatnim koncepcijama dobra, mogu se zasnivati na određenim tvrdnjama o dobru koje su najšire prihvaćene, bez obzira na to što mogu biti predmet sporova. Perfekcionistička politika ne mora biti kontroverzna u tom smislu da ugrožava socijalnu stabilnost ili povlači državnu represiju nad onima koji ne dijele određene vrijednosti. Umjereni je liberalni perfekcionizam ekumenskiji (po tomu, pluralističkiji), a s obzirom na to da uvažava poštovanje autonomije i prava pojedinaca ujedno i nesklon represiji, za razliku od »običnog « perfekcionizma. Kada se taj drugi formulira kao sistem vjerovanja koji se odnosi na krajnje svrhe, kao rigidno uređen sustav vrijednosti koji polazi od uvida o ljudskoj prirodi, izvrsnosti i napretku, u tom 
će slučaju oko njegovih principa najvjerojatnije postojati razložno neslaganje i bit će represivan prema onima koji ne dijele uvjerenja i vrijednosti dane koncepcije dobra. S druge strane, oko pojedinih »lokalnih « prosuđivanja $\mathrm{i}$ vrjednovanja, kao što je stajalište da su umjetnost, zdrav život, društvenost, autonomija i smislen rad značajna dobra, može biti postignuta razložna suglasnost i na taj način mogu legitimno biti prihvaćena pri političkom odlučivanju, zajedno sa stajalištima o osnovnim pravima i slobodama. Da je fizička aktivnost vrjednija od neaktivnosti prihvatit će i osoba koja preferira sjedenje ispred televizora, isto kao što su pušači u najvećem broju svjesni da ugrožavaju sebi zdravlje. Te osobe, također, neće imati razloga odbiti takve mjere kao što su promocija amaterskog sporta, ograničenje pušenja na određenim mjestima radi zaštite nepušača od pasivnog pušenja pa čak ni otvorenu zabranu pušenja kada je riječ o maloljetnicima. Javne razborite perfekcionističke mjere, kao što je promocija vrijednih aktivnosti i odvraćanje od onih štetnih, osobe mogu odobriti čak i kada neće imati koristi od tih mjera ili će im autonomija biti djelomično ograničena.

Razmotrimo sada primjedbe umjerenom perfekcionizmu, od kojih su prve dvije Quongove. Prema prvoj primjedbi, pitanje slažu li se sve razborite osobe oko poželjnosti pojedinih dobara jest empirijsko i iziskuje iscrpno ispitivanje sadržaja svih različitih razložnih sveobuhvatnih koncepcija dobra. Primjerice, da bi se otkrilo postoji li oko vrijednosti prijateljstva supstancijalna razložna suglasnost neophodno je analizirati sve točke gledišta, što je praktično neizvedivo, tako da će tvrdnja o općoj prihvaćenosti biti nepotpuna i neprecizna (usp. Quong 2011: 216; Quong 2014: 101). Na tu primjedbu može se odgovoriti da ona pretpostavlja kako je nespornost određenih lokalnih dobara prihvaćena sa stajališta svih koncepcija dobra, odnosno da građani moraju dijeliti širu moralnu teoriju. Kako vidimo na osnovi dosadašnje analize, oni mogu dijeliti samo pojedine vrijednosne stavove, primjerice da je ovisnost o drogama, alkoholu ili kocki loša. Dovoljno je ukazati na to da postoje dobra ili klase dobara koja su razložno prihvaćena kao vrijedna, odnosno koje nijedna osoba neće nerazložno odbaciti kao štetna ili diskriminirajuća.

Druga Quongova primjedba glasi da nije jasna motivacija perfekcionista za prihvaćanjem koncepta razložnog slaganja oko principa koji se mogu javno opravdati i na osnovi kojih se konstituira nepristrana koncepcija pravde. Perfekcionizam se može pozvati na vrijednosti i dobra direktno, s obzirom na to da njegova stajališta o dobrom životu već podrazumijevaju njihovu validnost, tako da bi sâmo pozivanje na razložni pluralizam i razložno slaganje bilo suvišno (usp. Quong 2011: 217). Na tu je primjedbu djelomično odgovorio Andrew Lister, ukazujući na to da ona ovisi o tome hoćemo li prihvatiti Quon-

9

To uviđa i sam Rawls kada piše: »Većina ljudi ne gleda na svoje religijske, filozofske $\mathrm{i}$ moralne doktrine kao na potpuno opće i obuhvatne, a to dozvoljava varijacija u stupnju. Tu ima dosta lutanja i mnogo načina da se liberalni principi pravde labavo vežu za ta (djelomično) obuhvatna gledišta, kao i mnogo načina da se u okvirima političkih principa pravde dozvoli afirmacija različitih (djelomično) obuhvatnih doktrina.« (Rawls 1998: 197)

10

Franz Mang stavove o dobrima koja doprinose valjanom životu svih ili gotovo svih osoba naziva »kvalificirana stajališta« i njih kao relevantna prihvaćaju svi građani. Chan smatra da takvi stavovi nisu kontroverzni, dok Richard J. Arneson kontroverznost ili neslaganje na nižem nivou općosti, odnosno kod primjene, uspoređivanja i davanja prednosti određenim dobrima, ne smatra preprekom za njihovo uvažavanje u moralnom opravdanju dane politike.

11

Alexandra Couto razlikuje običnu i umjerenu verziju perfekcionizma. Jedino obični perfekcionizam podrazumijeva obvezu države da djeluje perfekcionistički, čime podliježe prigovoru paternalizma (usp. Couto 2014: 6). 
govu konstrukciju i prihvatiti njegov koncept razložnosti (usp. Lister 2014: 32). Napomenimo da opća prihvaćenost ne znači da se pojedina »lokalna« dobra ne opravdavaju, tako da je i dalje neophodno obrazložiti spojivost tih dobara s drugim moralno-političkim principima kao što su sloboda, pravo, tolerancija ili poštovanje vrijednosti svakog pojedinca, kao i njihovu integraciju u legitimne i obranjive političke principe.

Sa strane antiperfekcionizma, može se uputiti primjedba da su pojedina dobra po svom karakteru nejavna i, prema tomu, ne mogu biti predmet političke deliberacije. To je očigledna razlika u odnosu na temeljne principe pravde $\mathrm{i}$ opravdanja u javnom umu koja su neophodna za te principe. Stoga je problematično je li politika adekvatni forum za raspravu o brojnim dobrima koja su općeprihvatljiva, odnosno mogu li se kroz državnu intervenciju ona ostvariti. Vrijednosti prijateljstva realiziraju se kao nejavne i ovdje bi primjedba o neadekvatnosti eksternog poticaja bila opravdana: ne mogu se stvarati prilike za prijateljstvo na javni način i država ne može promovirati ili ohrabrivati prijateljstvo. Javno se opravdanje, ipak, može dati poticaju uspostavljanja i održavanja »građanskog prijateljstva« kroz uzajamnost i solidarnost, a koje, kao i »privatno« prijateljstvo, može biti čvrsto bez obzira na ideološka, religijska i svjetonazorska razmimoilaženja osoba. U istom smislu, javni forum može odobravati političku autonomiju pojedinaca, dok istovremeno može odbaciti kontroverznu koncepciju autonomije kao djelovanje lišeno vanjskih pritisaka ili kao priznavanje krajnjeg autoriteta pojedinca kada je riječ o svim njegovim etičkim izborima.

Osim što su politička sredstva neprimjerena za neke perfekcionističke mjere, za druge mogu biti nepoželjna. Prema Chanovu određenju, umjereno perfekcionistička država

»... promovira vrijedna dobra, kao što su umjetnosti, obiteljski život i osnovne ljudske vrline i odvraća ljude od načina života koji u krajnjoj mjeri oskudijeva u tim dobrima.« (Chan 2000: 14)

Premda odmah zatim napominje da državi nije potrebno praviti daljnju razliku između onih načina života koji su »dovoljno dobri«, takva formulacija vodi $\mathrm{k}$ »prisilnom perfekcionizmu«, koji i sam Chan odbacuje. Država može promovirati umjetnost i obiteljski život, ali ne i odvraćati ili na bilo koji način ometati one koji daju prednost gledanju sportskih utakmica ili preferiraju živjeti sami ili u alternativnim zajednicama. Ovdje je riječ o životnim stilovima pri kojima država nije ovlaštena prisiljavati na jedan ili drugi način života. Drugačiji je slučaj s aktivnostima koje su škodljive. Država neosporno treba ograničavati one načine života koji imaju za posljedicu velike troškove drugih ljudi, kao što je to kod pasivnog pušenja, no manje je očigledno ovlaštenje države za intervenciju usmjerenu prema dobrobiti samih pušača. Kod restriktivnih mjera protiv pušenja politika mora odražavati prioritete, pri čemu je riječ o davanju prednosti jednom razlogu, ujedno ne odbacujući kao nerazumne druge razloge: kada se daje prednost preventivi nanošenja štete zdravlju, uzima se u obzir i autonomija kao izbor zadovoljstva u pušenju.

\section{Zaključak}

Nastojao sam pokazati kako rawlsovska neutralna liberalistička pozicija ne uzima u obzir kompleksnost koncepcija dobra, odnosno razlike među koncepcijama dobra kao filozofsko-etičkih teorija, religijskih doktrina $\mathrm{i} » l o k a l-$ nih« vrijednosnih poimanja dobrobiti i štetnosti određenih praksi. Također, branim pretpostavku da, ako plediraju biti sastavnim dijelom političkog polja 
javnog uma, te koncepcije moraju biti razložne, odnosno biti u dovoljnoj mjeri koherentne i ne ignorirati evidenciju i norme logičkog rasuđivanja. Tako se antivakcinizam može pozivati na liberalne vrijednosti poput autonomije, ali ga ipak neosnovanost njegovih osnovnih postavki uvrštava u nerazložne doktrine.

U završnom dijelu rada ispitao sam opravdanost određenih primjedbi neutralnog liberalizma poziciji umjerenog liberalističkog perfekcionizma, takvoj koja pretpostavlja da javno promoviranje određenih dobara i restrikcija štetnih aktivnosti niti moraju biti paternalističkim i diskriminatornim niti se ovo promoviranje i restrikcije nužno opravdavaju sa stajališta sveobuhvatnih doktrina. Pritom, time nisu iscrpljene sve primjedbe koje se mogu uputiti umjerenom perfekcionizmu, kao što su i same primjedbe iz prethodnih paragrafa, zajedno s odgovorima, samo skice koje zahtijevaju daljnju razradu. Neophodno je da ta pozicija razjašnjava na koji način etički koncepti i norme koje su valjane u privatnoj sferi mogu imati svoju političku interpretaciju, pritom održavajući razliku sfere privatne upotrebe i javnog foruma. Također, potrebno je imati u vidu raznovrsnost i kompleksnost perfekcionističkih mjera, kao što su stvaranje i održavanje opcija, javno zastupanje, obeshrabrivanje i restrikcija dobara, što iziskuje daljnje promišljanje kompetencije i granice ovlaštenja državnog interveniranja.

\section{Literatura}

Arneson, Richard J., »Liberal Neutrality on the Good: An Autopsy«, u: Steven Wall, George Klosko (ur.), Perfectionism and Neutrality: Essays in Liberal Theory, Rowman \& Littlefield Publishers, Lanham 2006., str. 191-218.

Chan, Joseph, »Legitimacy, Unanimity, and Perfectionism «, Philosophy \& Public Affairs 29 (2000) 1, str. 5-42, doi: https://doi.org/10.1111/j.1088-4963.2000.00005.x.

Couto, Alexandra, Liberal Perfectionism, De Gruyter, Berlin, Boston 2014.

Gaus, Gerald F., »The Diversity of Comprehensive Liberalisms«, u: Gerard F. Gaus, Chandran Kukathas (ur.), Handbook of Political Theory, SAGE Publications Ltd., London 2004., str. 100-114.

Lister, Andrew, »Public Reason and Perfectionism: Comments on Quong's Liberalism Without Perfection«, Filozofija i društvo 25 (2014) 1, str. 12-34, doi: https://doi.org/10.2298/ fid14010121.

Mang, Franz Fan-lun, »Liberal Neutrality and Moderate Perfectionism«, Res Publica 19 (2013) 4, str. 297-315, doi: https://doi.org/10.1007/s11158-013-9232-8.

McCabe, David, »Knowing About Good: A Problem with Antiperfectionism«, Ethics 110 (2000) 2, str. 311-338, doi: https://doi.org/10.1086/233271.

Nussbaum, Martha C., »Perfectionist Liberalism and Political Liberalism«, Philosophy \& Public Affairs 39 (2011) 1, str. 3-45, doi: https://doi.org/10.1111/j.1088-4963.2011.01200.x.

Pallikkathayil, Japa, »Neither Perfectionism nor Political Liberalism«, Philosophy \& Public Affairs 44 (2016) 3, str. 171-196, doi: https://doi.org/10.1111/papa.12077.

Quong, Jonathan, Liberalism without Perfection, Oxford University Press, Oxford 2011.

Quong, Jonathan, »Liberalism without Perfection: Replies to Lister, Kulenovic, Zoffoli, Zelic, and Baccarini«, Filozofija i društvo 25 (2014) 1, str. 96-122, doi: https://doi. org/10.2298/fid1401096q.

Rawls, John, »Justice as Fairness: Political not Metaphysical«, Philosophy \& Public Affairs 14 (1985) 3, str. 223-251.

Rawls, John, A Theory of Justice, The Belknap Press, Cambridge 1999. 
Raz, Joseph, The Morality of Freedom, Clarendon Press, Oxford 1988.

Rols, Džon [Rawls, John], Politički liberalizam, prevela Ljiljana Nikolić, Filip Višnjić, Beograd 1998.

Schefczyk, Michael, »Neutralism, Perfectionism and Respect for Persons«, Ethical Perspectives 19 (2012) 3, str. 535-546, doi: https://doi.org/10.5167/uzh-96847.

Waldron, Jeremy, »Autonomy and Perfectionism in Raz's Morality of Freedom «, Southern California Law Review 62 (1989) 3-4, str. 1097-1152.

Wall, Steven, Liberalism, Perfectionism and Restraint, Cambridge University Press, Cambridge 1998 .

Weithman, Paul, »In Defense of a Political Liberalism«, Philosophy \& Public Affairs 45 (2017) 4, str. 397-412, doi: https://doi.org/10.1111/papa.12100.

Zelić, Nebojša; Baccarini, Elvio, »Rawlsova teorija pravednosti i pitanje istine«, Filozofska istraživanja 121 (2011) 31, str. 65-83.

Zelić, Nebojša, »Public Equality, Public Reason and Liberal Community«, Anali Hrvatskog politološkog društva 12 (2015) 1, str. 45-62.

\title{
Michal Sládeček
}

\section{Comprehensiveness and Reasonableness of the Conceptions of the Good in the Dispute of Political Liberalism and Perfectionism}

\begin{abstract}
The paper argues that Rawls' critique of perfectionism from the standpoint of neutral liberalism scrutinizes the conceptions of the good without demarcation between them, that is, without distinguishing whether they are comprehensive religious or philosophical conceptions, or whether they are piecemeal comprehensions of local values, concepts and goods. In addition to the high contestability in the use of the concept of comprehensiveness, it is necessary to retain the concept of reasonableness, as comprehensions of the good have to be to some extent well-founded, consistent and coherent to be considered relevant in a political dispute. Considering these distinctions, it can be claimed that, in particular cases, the application of considerations of the good in disputes concerning constitutional essentials can be supported and, considering reasonable pluralism, morally justified. Nevertheless, moderate perfectionism has to specify whether political decisions create and support options, promote valuable goods or they discourage worthless goods. It is necessary to delineate the limits of perfectionistic measures accordingly.
\end{abstract}

\section{Keywords}

neutrality, liberalism, perfectionism, reasonable conceptions of the good, doctrines, John Rawls 